\title{
Alterations in mRNA expression of steroid receptors and heat shock proteins in the liver of rare minnow (Grobiocypris rarus) exposed to atrazine and $\mathrm{p}, \mathrm{p}^{\prime}-\mathrm{DDE}$
}

\author{
Lihua Yang, Jinmiao Zha, Xiaoyan Zhang, Wei Li, Zhaoli Li, Zijian Wang* \\ State Key Laboratory of Environmental Aquatic Chemistry, Research Center for Eco-Environmental Sciences, Chinese Academy of Sciences, P.O. Box 2871, Beijing 100085, China
}

\section{A R T I C L E I N F O}

\section{Article history:}

Received 19 December 2009

Received in revised form 8 March 2010

Accepted 14 March 2010

\section{Keywords:}

Atrazine

p,p'-DDE

Rare minnow (Gobiocypris rarus)

Heat shock proteins

Steroid receptors

\begin{abstract}
A B S T R A C T
The chaperon role of heat shock proteins (HSPs) throughout the life cycle of steroid receptors have been demonstrated in vitro. However, the actions of HSPs in steroid pathways in animals especially in fish were unclear. In this study, sexually mature rare minnows (Gobiocypris rarus) were exposed to typical endocrine disruptors (atrazine and p,p'-DDE). Hypertrophy of hepatocytes at the $333 \mu \mathrm{g} / \mathrm{l}$ atrazine treatment and atrophy of hepatocytes in all p, $\mathrm{p}^{\prime}$-DDE treatments were observed. The expression of liver $h s p 70$ and $h s p 90$ in atrazine treatments were significantly up-regulated. Moreover, remarkable increases in the expression of androgen receptor ( $a r)$ and estrogen receptor (er) were observed, while alterations of the glucoticorcoid receptor ( $g r$ ) expression was not significant in atrazine exposed fish. The expression of $a r, e r, g r, h s p 70$ and $h s p 90$ were significantly suppressed following p,p'-DDE exposure. These results demonstrate that the expression of $h s p 70$ and $h s p 90$ is altered along with changes of steroid receptors in vivo. Therefore, the results are consistent with the possibility that in fish heat shock proteins (HSPs) play chaperon roles for the steroid receptors in vivo, which also concurs with previous in vitro mammalian studies.
\end{abstract}

(c) 2010 Elsevier B.V. All rights reserved.

\section{Introduction}

In recent years the highly conserved family of heat shock proteins (HSPs) has received extensive attention for their roles in response to stress. A chaperon role of HSPs throughout the life cycle of steroid receptors (the androgen receptor (AR), estrogen receptor (ER) and glucoticorcoid receptor (GR), etc.) has been demonstrated in vitro by both biochemical experiments (Scherrer et al., 1990; Reik et al., 1991) and RNA interference in mammalian tissue culture cells (Whitesell and Cook, 1996). However, the roles of HSPs in steroid pathways in animals especially in fish were still not clear. Since many endocrine disruptions were thought to result from the interactions between contaminants and the steroid receptors (McLachlan, 1993), it is important to find out the actions of HSPs in steroid pathways when fish were exposed to environmental contaminants.

Atrazine (2-chloro-4-ethylamino-6-isopropyl-amino-striazine) is a triazine herbicide widely used for the control of weeds and grasses. Atrazine concentrations up to $108 \mu \mathrm{g} / \mathrm{l}$ have been reported in rivers of North America (USEPA, 2002). In China, atrazine concentrations exceeding the standards for drinking water $(3 \mu \mathrm{g} / \mathrm{l})$ have also been reported in Guanting reservoir

\footnotetext{
* Corresponding author. Tel.: +86 10 62849140; fax: +86 1062929140 .

E-mail address: wangzj@rcees.ac.cn (Z. Wang).
}

(Ren et al., 2002) and Taihu Lake (Dong et al., 2006). p,p'-DDE (1,1-dichloro-2,2-bis(p-chlorophenyl)-ethylene) is the major metabolite of the insecticide dichlorodiphenyltrichloroethane (DDT) which has been banned in many countries. However, DDT and its degradates (DDE and DDD) are still consistently detected in river water and sediments of many countries (Peris et al., 2005; Xue et al., 2006). For instance, p,p'-DDE concentrations up to $546 \mathrm{ng} / \mathrm{l}$ have been recently reported in the Beijing Guanting reservoir, China (Xue et al., 2006). These compounds are prone to accumulate in different tissues (Harshbarger et al., 2000) and thus may pose a significant risk to aquatic organisms. Both atrazine and p, $\mathrm{p}^{\prime}$-DDE have been demonstrated to cause endocrine disruptions: atrazine was shown to promote the conversion from androgens to estrogens by inducing the activity of aromatase (Crain et al., 1997); while p,p'-DDE turned out to be a potent androgen antagonist (Kelce et al., 1995). However, their effects on HSPs have rarely been reported (Dowling et al., 2006).

Rare minnow (Gobiocypris rarus) is considered to be an appropriate species for the assessment of endocrine disrupting chemicals due to its small size, ease of culture, short life cycle and prolific egg production with high fertilization and hatching rates (Wang, 1992; Zha et al., 2007). Effects on the gonadal and thyroid systems by environment pollutants have been demonstrated in rare minnow (Zha et al., 2007; Zhang et al., 2008; Li et al., 2009).

In this study sexually mature rare minnow were exposed to environmentally relevant concentrations of atrazine and p,p'-DDE. 
The objective was to determine the actions of HSPs in steroid signaling pathways in fish. Relative expression of the heat shock proteins ( $h s p 70$ and $h s p 90$ ) and steroid receptors ( $a r, e r$ and $g r$ ) in the liver of rare minnow was determined. In addition, hepatosomatic indices (HSI) and histopathological lesions were examined to evaluate the general status of the liver tissue.

\section{Materials and methods}

\subsection{Test fish and culture conditions}

The rare minnow have been maintained in our laboratory for more than 6 years. The brood stock is kept in flow-through system with dechlorinated tap water and a 16:8 h of light:dark photoperiod at $25 \pm 1^{\circ} \mathrm{C}$ and fed newly hatched brine shrimp (Artemia nauplii) twice and granular food (TetraMin, Tetra Werke, Melle, Germany) once a day.

\subsection{Chemicals}

Atrazine and acetone were purchased from Sigma (Chemical Co., USA), and p, $\mathrm{p}^{\prime}$-DDE from Chem Service (West Chester, PA, USA).

\subsection{Experimental protocol}

Fish were kept under flow-through conditions at $25 \pm 1^{\circ} \mathrm{C}$ with a photoperiod of 16:8 h (light:dark), and generally fed with a commercial granular food (Tetra, Germany) at a rate of $0.1 \%$ body weight per day and newly hatched brine shrimp (A. nauplii) twice a day. Wastes and residues were removed daily and the test equipment and chambers were cleaned once a week.

Experiment 1 : Sexually mature fish $(n=210), \sim 8$ months old and the offspring from the same pair of brood stock, were randomly divided into seven groups (sex ratio 1:1). After acclimating for 2 weeks, fish were exposed to various concentrations of atrazine (3, $10,33,100,333 \mu \mathrm{g} / \mathrm{l})$ for 28 days.

Experiment 2: Sexually mature fish $(n=210), \sim 10$ months old and the offspring from the same pair of brood stock, were randomly divided into seven groups (sex ratio 1:1). After acclimating for 2 weeks, fish were exposed to various concentrations of $\mathrm{p}, \mathrm{p}^{\prime}$-DDE $(0.1,0.5,2,10,50 \mu \mathrm{g} / \mathrm{l})$ for 28 days.

The solvent control aquaria received a combination of acetone and water $(1: 100,000, v / v)$, whereas the water control aquaria received dechlorinated tap water only. The stock solutions were prepared every 2 days in high-performance liquid chromatography-grade acetone and delivered to glass mixing vessels by means of a peristaltic pump at a rate of $1 \mathrm{ml} / \mathrm{min}$. Then, the solutions were diluted with dechlorinated tap water flowing into the mixing vessels at a rate of $41 / \mathrm{h}$, which ensured a retention time shorter than $4 \mathrm{~h}$ and tank water replacement with at least 6 volumes a day.

Fish were sacrificed at the end of the exposure. Whole-body and liver weights were determined. Liver tissue from four males and four females in each group was fixed in Bouin's solution (71\% saturated picric acid, $24 \%$ formaldehyde, $5 \%$ glacial acetic acid; Sigma-Aldrich, USA), and tissues from the remaining male and female rare minnow were flash-frozen in liquid nitrogen, and stored at $-80^{\circ} \mathrm{C}$.

\subsection{Hepatosomatic indices}

Hepatosomatic indices (HSI) of female and male rare minnow were calculated as follows:

$\mathrm{HSI}=\left(\frac{\text { liver weights }(\mathrm{g})}{\text { body weights }(\mathrm{g})}\right) \times 100$
Table 1

Sequences of primers used for RT-PCR.

\begin{tabular}{|c|c|c|c|}
\hline Gene & GenBank no. & Primer sequences $\left(5^{\prime}-3^{\prime}\right)$ & $\begin{array}{l}\text { Product } \\
\text { size (bp) }\end{array}$ \\
\hline er & EF190319 & $\begin{array}{l}\text { Forward: AACAGACCGCCACATTAG } \\
\text { Reverse: GAGCCACCTGAGATTTACC }\end{array}$ & 340 \\
\hline ar & GQ241735 & $\begin{array}{l}\text { Forward: GACTTCCAGGTTTCCGTAAC } \\
\text { Reverse: TGGACCGAGATGATTTCTG }\end{array}$ & 178 \\
\hline$g r$ & FJ410931 & $\begin{array}{l}\text { Forward: GAGAACTCCAGCCAGAACTG } \\
\text { Reverse: CCACGCTCAGAGATTTATTCAC }\end{array}$ & 126 \\
\hline hsp70 & FJ410933 & $\begin{array}{l}\text { Forward: CTCATTGGGCGACGATTT } \\
\text { Reverse: CCTTTGTATTCAACCTGGACCT }\end{array}$ & 110 \\
\hline hsp90 & FJ827029 & $\begin{array}{l}\text { Forward: CACTCTCAGTTCATCGGTTACC } \\
\text { Reverse: TCCTTGACCTTCTTCTTCCTC }\end{array}$ & 297 \\
\hline
\end{tabular}

\subsection{Histopathology}

After $24 \mathrm{~h}$, liver samples fixed in Bouin's solution were transferred to $70 \%$ ethanol and processed according to standard histological methods and embedded in paraffin wax as described by Wolf et al. (2004). The sections were cut at 3-4 $\mu \mathrm{m}$, stained with hematoxylin and eosin, and observed on a Axioskop 2 mot plus optical microscope (Zeiss, Germany) and digitized with a AxioCam digital camera (Zeiss) using the Application Suite software AxioVision Rel. 4.5 (Zeiss). Diameters of hepatocytes were measured as described by Kokolakis et al. (2008).

\subsection{Preparation of $c D N A$ from liver of rare minnow}

Total RNA was isolated using SV total RNA isolation system (with DNase I, promega, USA), and the RNA samples were dissolved in ribonuclease-free water and stored at $-80^{\circ} \mathrm{C}$.

Subsequently, the reverse transcription reaction mixtures containing $10 \mu \mathrm{l}$ total RNA extract plus $2 \mu \mathrm{l}(0.05 \mu \mathrm{g} / \mu \mathrm{l})$ of Oligo(dT) ${ }_{15}$ were heated to $70^{\circ} \mathrm{C}$ for $5 \mathrm{~min}$ and quickly chilled on ice for $30 \mathrm{~s}$. Then a solution containing $50 \mathrm{mM}$ Tris- $\mathrm{HCl}$ buffer ( $\mathrm{pH} 8.3$ ), $75 \mathrm{mM}$ $\mathrm{KCl}, 10 \mathrm{mM}$ dithiothreitol, $3 \mathrm{mM} \mathrm{MgCl}_{2}, 2 \mathrm{mM}$ deoxynucleotide triphosphate (10 mM each), 40 units of RNAasin (RNAase inhibitor; Promega), and $200 \mathrm{U}$ of Moloney Murine Leukemia Virus Reverse Transcriptase (Promega) was added to a total volume of $25 \mu l$ and incubated for $1 \mathrm{~h}$ at $37^{\circ} \mathrm{C}$. Thereafter, the reaction mixture was heated to $70^{\circ} \mathrm{C}$ for $10 \mathrm{~min}$ to inactivate the reverse transcription. The samples were stored at $-20^{\circ} \mathrm{C}$ until analysis.

\subsection{Quantitation by real-time PCR}

Real-time PCR was performed in Mx3005P real-time quantitative polymerase chain reaction system (Stratagene, USA) in a total volume of $25 \mu \mathrm{l}$, comprised of $1 \mu \mathrm{l}$ cDNA, $12.5 \mu \mathrm{l}$ Brilliant II SYBR Green QPCR master mix ( $2 \times$, Stratagene, USA), $300 \mathrm{nM}$ forward primer and $300 \mathrm{nM}$ reverse primer, and diethyl pyrocarbonatetreated water. The primer pairs used for real-time PCR are shown in Table 1 . The cycling conditions used were: an initial denaturation step of $95^{\circ} \mathrm{C}$ for $10 \mathrm{~min}$, followed by 40 cycles of $95^{\circ} \mathrm{C}$ for $30 \mathrm{~s}, 57^{\circ} \mathrm{C}$ for $40 \mathrm{~s}$ and $72^{\circ} \mathrm{C}$ for $30 \mathrm{~s}$, and the last cycle of $95^{\circ} \mathrm{C}$ for $30 \mathrm{~s}, 57^{\circ} \mathrm{C}$ for $30 \mathrm{~s}$ and $72^{\circ} \mathrm{C}$ for $60 \mathrm{~s}$ for dissociation curve. Dissociation curve analysis for each amplification displayed a single peak, indicating that there was no amplification of untargeted genes (data not shown). The control, containing all the reaction components except for the template, was included in all experiments.

All the samples were analyzed twice and each reaction was performed in triplicate. The mean values were used for calcula- 


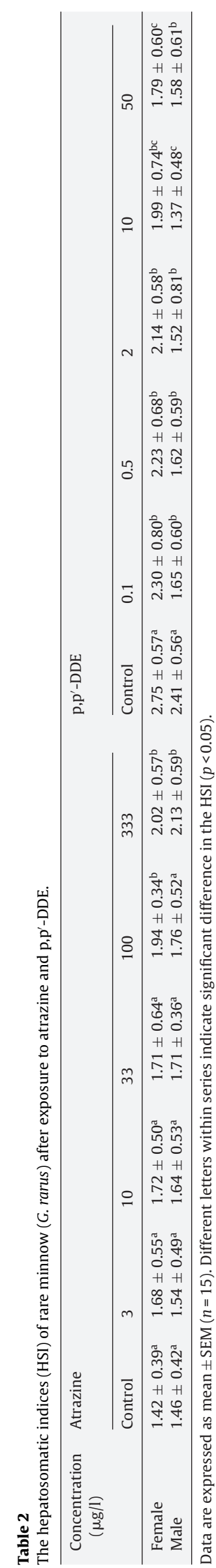

tions of mRNA expression. Relative expression of er, ar, gr, hsp70 and hsp90 mRNA expression were calculated using a delta-delta $\mathrm{Ct}$ method. For relative quantification, $\beta$-actin was used as an internal standard, and the validity was evaluated by $\lambda$ poly $(A)^{+}$ RNA-A (Takara) as an external standard as described by Ojima et al. (2005). The results showed no significant difference in the amounts of $\beta$-actin mRNA in control and vinclozolin exposed groups.

\subsection{Statistical analysis}

All quantitative data are expressed as means \pm SEM. Statistical analysis of variance was performed with one-way ANOVA, SPSS (version 13.0; USA); the Levene test of homogeneity of variance and Dunnett's test were used to compare treatment means. Pearson correlation analysis was used to determine the relationship between changes of gene expression and exposure concentrations. A probability of $p<0.05$ was considered statistically significant.

\section{Results}

\subsection{Growth and hepatosomatic indices (HSI)}

No significant difference in HSI was observed between the solvent control and water control in either experiment.

Compared to the control, atrazine caused significant increases of HSI in females exposed to atrazine at $100,333 \mu \mathrm{g} / \mathrm{l}$ and males at $333 \mu \mathrm{g} / \mathrm{l}$, respectively. However, the HSI was significantly decreased in male and female rare minnow at all concentrations of p,p'-DDE (Table 2).

\subsection{Histopathology}

Normal hepatic tissue exhibited regular array of the hepatocytes with evident, well-defined nuclei (Fig. 1A and D). The average sizes of hepatocytes in males and females were $10.0 \pm 0.9 \mu \mathrm{m}$ and $10.4 \pm 1.3 \mu \mathrm{m}$, respectively.

Microphotographs revealed hypertrophy of hepatocytes in both male and female rare minnow treated by atrazine at the higher concentration ( $333 \mu \mathrm{g} / \mathrm{l}$ ) (Fig. 1B and E). One-way ANOVA revealed significant increases in the diameters of hepatocytes at $333 \mu \mathrm{g} / \mathrm{l}$ both in males $(11.2 \pm 1.4 \mu \mathrm{m})$ and females $(11.3 \pm 1.3 \mu \mathrm{m})$ compared to the control $(p<0.05)$.

Atrophy and vacuolization of hepatocytes were noticed in all p,p'-DDE treatments (Fig. 1C and F). One-way ANOVA revealed significant decreases in the diameters of hepatocytes in females $(7.3 \pm 0.9 \mu \mathrm{m})$ and males $(8.7 \pm 1.3 \mu \mathrm{m})$ at $\mathrm{p}, \mathrm{p}^{\prime}$-DDE concentration of $50 \mu \mathrm{g} / \mathrm{l}$ compared to the control $(p<0.05)$.

\subsection{Results of real-time $P C R$}

No significant difference was observed between the solvent control and water control in the expression of all genes determined.

Atrazine exposure resulted in 2-fold increases in the expression of liver ar $(\geq 33 \mu \mathrm{g} / \mathrm{l})$ and $\operatorname{er}(\geq 33 \mu \mathrm{g} / \mathrm{l})$ in females, and ar $(\geq 100 \mu \mathrm{g} / \mathrm{l})$, er $(\geq 33 \mu \mathrm{g} / \mathrm{l})$ in males $(p<0.05)$. For both sexes, ar and er gene expression was dose dependent, the greatest induction (about 5-fold) occurring with the ar gene in females at the highest atrazine exposure level. Pearson correlation analysis further indicated positive relationships between $a r$, er expression and atrazine concentrations $(p<0.05)$. No effect on the expression of liver $g r$ mRNA was observed in rare minnow exposed to atrazine (Fig. 2).

The expression of liver $h s p 70$ showed 2-fold or higher increases at all treatments by atrazine except for $333 \mu \mathrm{g} / \mathrm{l}$ in females; the 


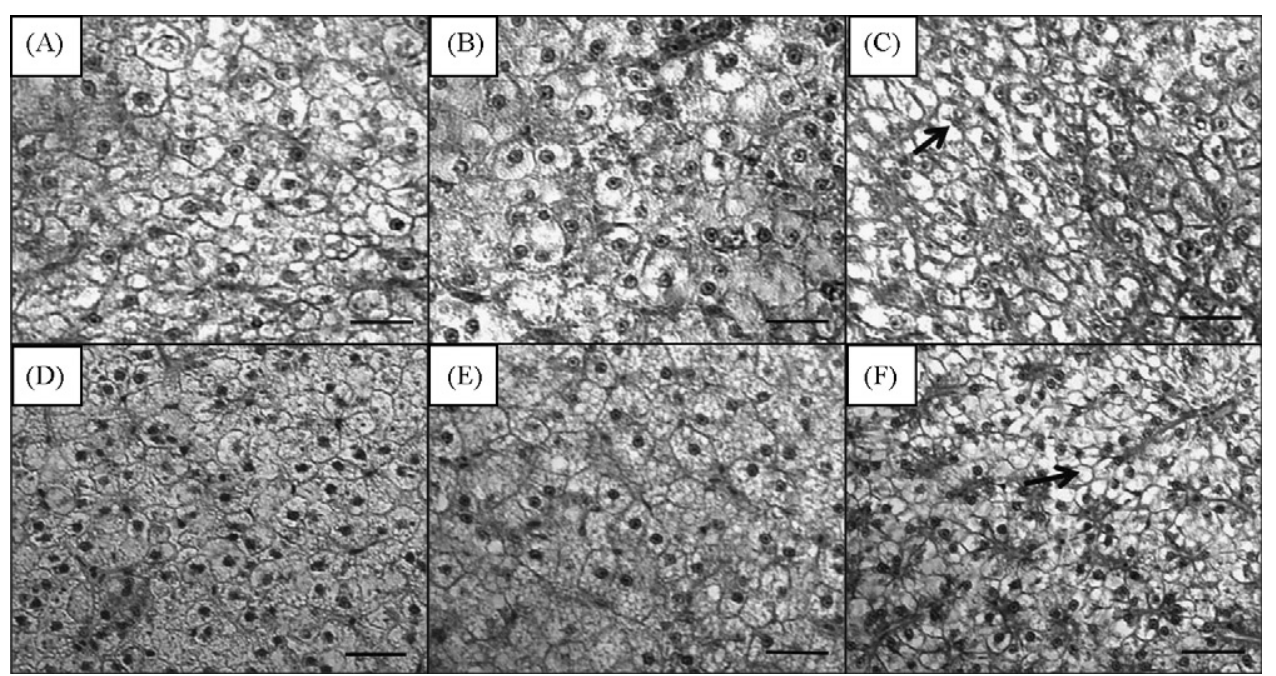

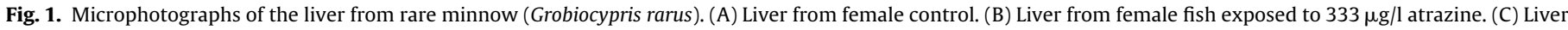

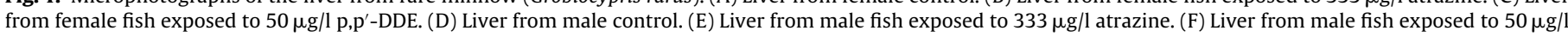
p,p'-DDE. Arrow shows vacuolization; bar $=20 \mu \mathrm{m}$.

(A) 6

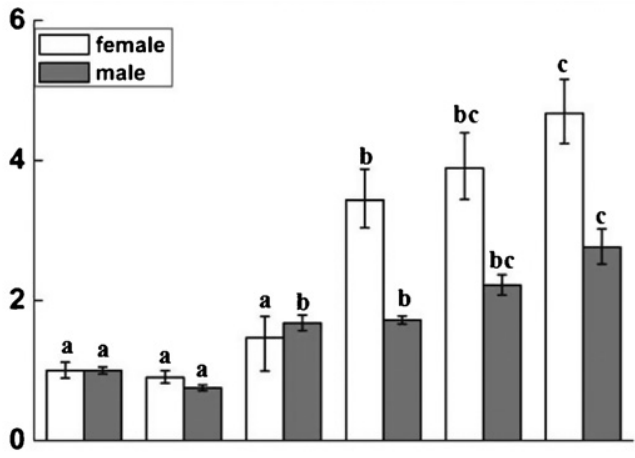

(B)
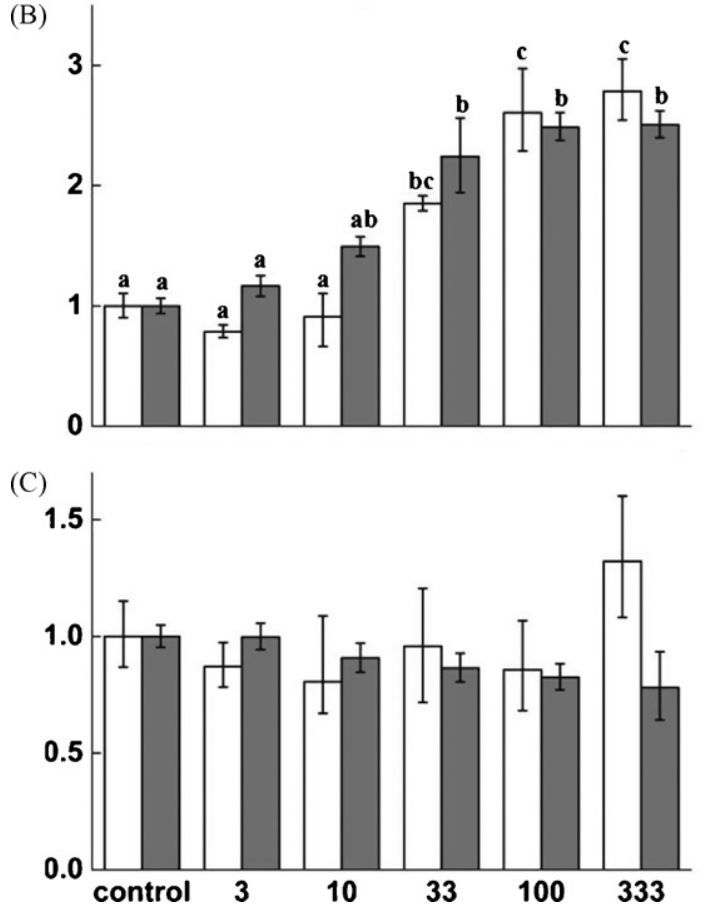

Fig. 2. Effects of atrazine on the expression of $\operatorname{ar}(\mathrm{A}), \operatorname{er}(\mathrm{B})$ and $\operatorname{gr}(\mathrm{C})$ in the liver of rare minnow (G. rarus) Horizontal axis represents atrazine concentrations ( $\mu \mathrm{g} / \mathrm{l}$ ); and vertical axis represents relative expression of target genes (fold). Data are expressed as mean \pm SEM $(n=6)$. Different letters within each series indicate significant difference in relative expression of target genes (Dunnett's test; $p<0.05$ ). response followed a dose-dependent relationship up to the maximum (14-fold increase) at $33 \mu \mathrm{g} / \mathrm{l}$. In the case of $h s p 90$, a 3-fold increase occurred at 3 and $333 \mu \mathrm{g} / 1$ in both males and females $(p<0.05)$ (Fig. 3)

Significant decreases (more than 2-fold) were observed in the expression of liver ar ( $\geq 10 \mu \mathrm{g} / \mathrm{l})$, er (all concentrations), $g r$ $(\geq 0.5 \mu \mathrm{g} / \mathrm{l})$ in females $(p<0.05)$, and $\operatorname{ar}(\geq 0.5 \mu \mathrm{g} / \mathrm{l})$, er $(\geq 0.5 \mu \mathrm{g} / \mathrm{l}), \mathrm{gr}$ (all concentrations) in males $(p<0.05)$ after exposure to $\mathrm{p}, \mathrm{p}^{\prime}$-DDE (Fig. 4). Pearson correlation analysis indicated negative relationships between dose and the expression profiles of liver $a r, g r$ in both males and females and er in males $(p<0.05)$; but not in er expression in females $(p=0.97)$.

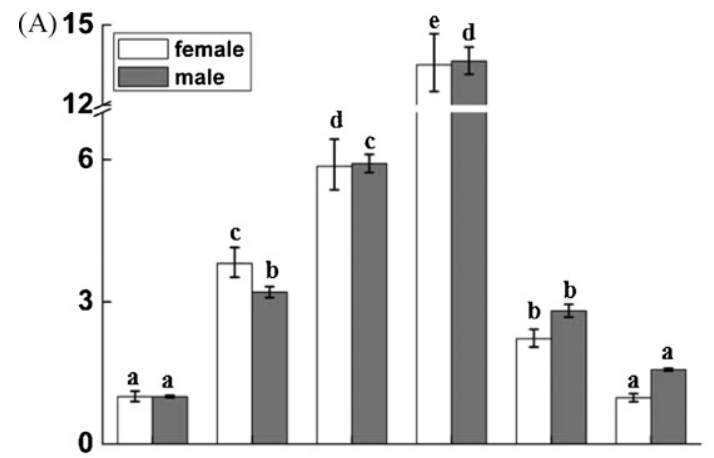

(B)

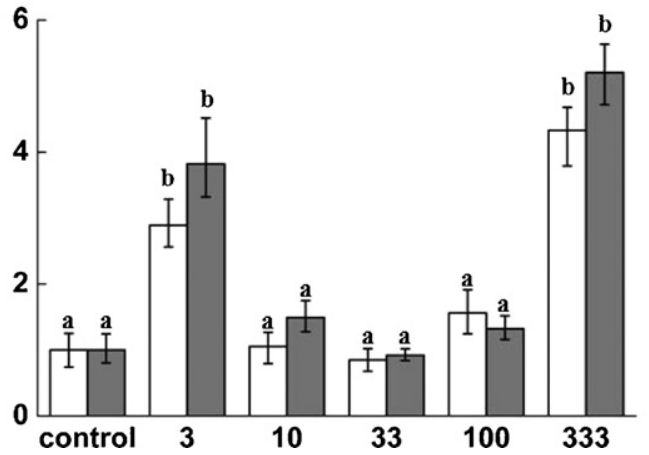

Fig. 3. Effects of atrazine on the expression of $h s p 70$ (A) and $h s p 90$ (B) in the liver of rare minnow (G. rarus). Horizontal axis represents atrazine concentrations $(\mu \mathrm{g} / \mathrm{l})$ and vertical axis represents relative expression of target genes (fold). Data are expressed as mean $\pm \operatorname{SEM}(n=6)$. Different letters within each series indicate significant difference in relative expression of target genes (Dunnett's test; $p<0.05$ ). 


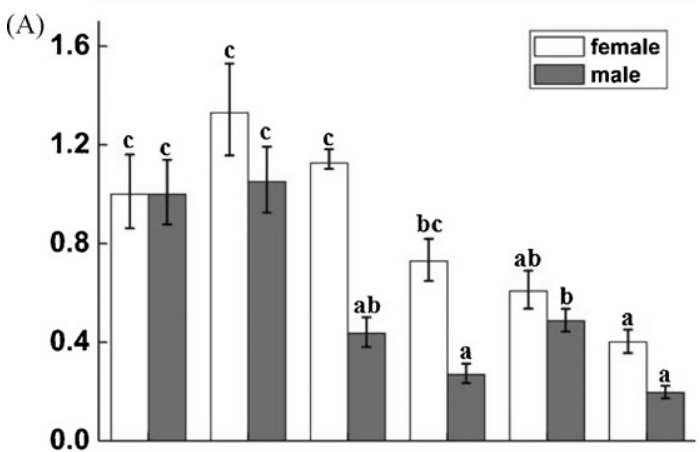

(B)
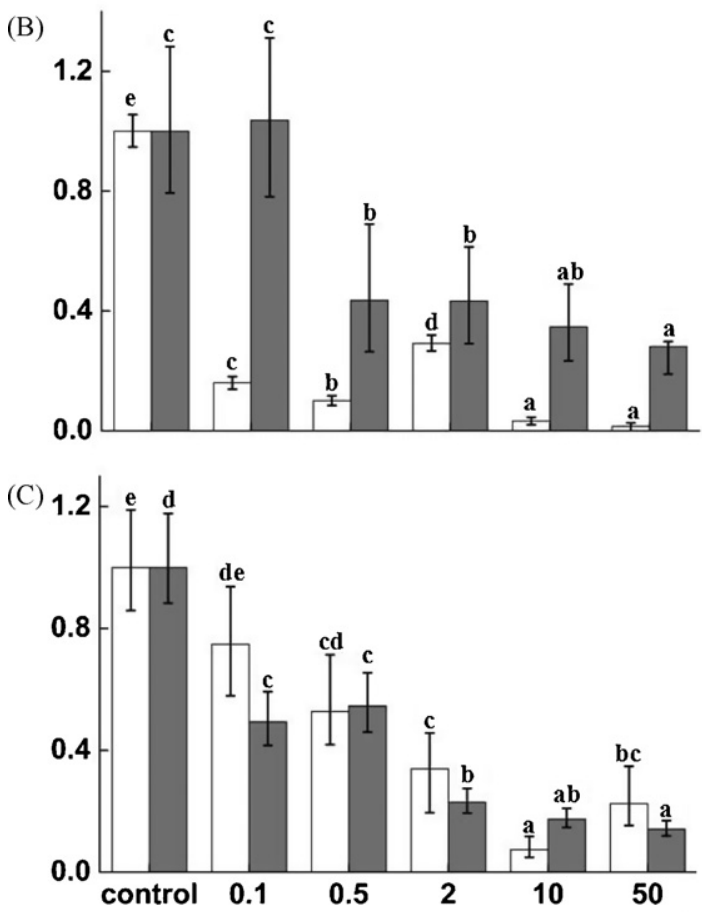

Fig. 4. Effects of $\mathrm{p}, \mathrm{p}^{\prime}-\mathrm{DDE}$ on the expression of $\operatorname{ar}(\mathrm{A})$, er (B) and $g r(\mathrm{C})$ in the liver of rare minnow (G. rarus). Horizontal axis represents p, $\mathrm{p}^{\prime}$-DDE concentrations $(\mu \mathrm{g} / \mathrm{l})$ and vertical axis represents relative expression of target genes (fold). Data are expressed as mean \pm SEM $(n=6)$. Different letters within each series indicate significant difference in relative expression of target genes (Dunnett's test; $p<0.05$ ).

More than 5-fold decreases were observed in the expression of liver $h s p 70$ and $h s p 90$ in both males and females at all concentrations of $\mathrm{p}, \mathrm{p}^{\prime}-\mathrm{DDE}(p<0.01)$ (Fig. 5).

\section{Discussion}

Many endocrine alterations occur by direct interactions between environmental contaminants and steroid receptors (Park et al., 2007) but other mechanisms that influence transcriptional rates are possible. HSPs have been shown in vitro to act as steroid receptor chaperons in mammalian systems (Reik et al., 1991). Although their role in fish steroid signaling pathways remains to be fully elucidated, it is possible that endocrine disruptors may act on HSPs and thereby affect genetic transcription. As a first step in this line of investigation, therefore, the relative expression of heat shock proteins ( $h s p 70$ and $h s p 90$ ) was examined in relation to steroid receptors ( $a r$, er and $g r$ ) in the liver of rare minnow. Overall, the results are consistent with indirect endocrine modulator effects mediated through HSPs.

HSI and histopathological lesions served in these experiments to evaluate the general status of the liver tissue. HSI have been

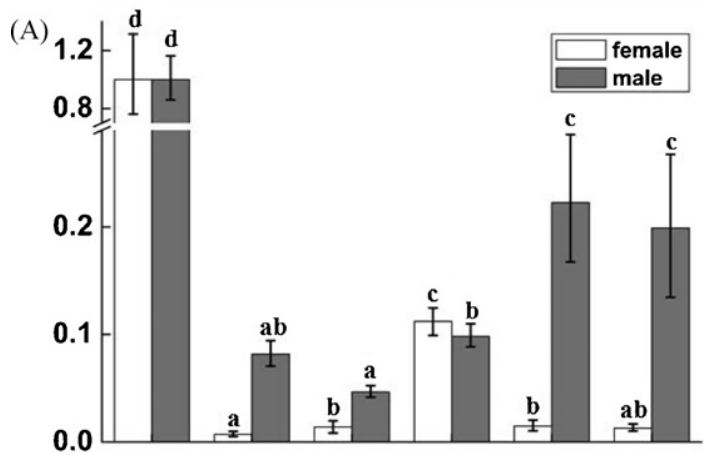

(B) 1.2

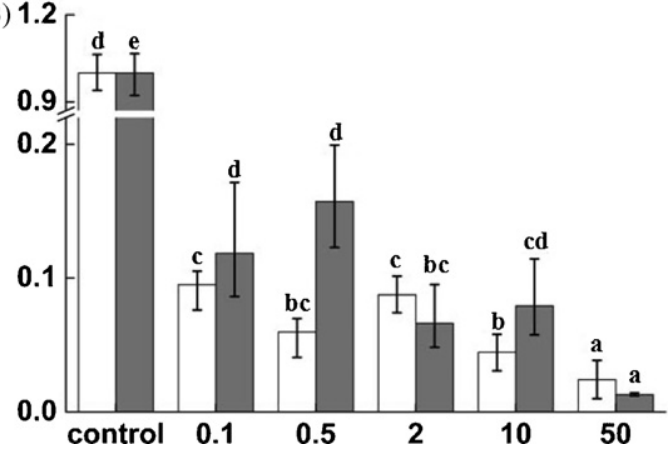

Fig. 5. Effects of p,p'-DDE on the expression of $h s p 70$ (A) and $h s p 90$ (B) in the liver of rare minnow (G. rarus). Horizontal axis represents p, $\mathrm{p}^{\prime}$-DDE concentrations $(\mu \mathrm{g} / \mathrm{l})$ and vertical axis represents relative expression of target genes (fold). Data are expressed as mean \pm SEM $(n=6)$. Different letters within each series indicate significant difference in relative expression of target genes (Dunnett's test; $p<0.05$ ).

used as physiological biomarkers to reflect responses following toxicant exposure and provide information on energy reserves and the general health of the organism (Van der Oost et al., 2003). In the present study, HSI showed a dose-dependent increase in atrazine treatments (Table 2). Zhong et al. (2004) and Zha et al. (2007) have reported increased HSI in rare minnow exposed to diethylstilbestrol for 21 days and ethynylestradiol for 28 days, respectively. The increases of HSI also have been found following exposure to estradiol in male flounder (Platichthys flesus) (Korsgaard et al., 1983) and rainbow trout (Oncorhynchus mykiss) (Christiansen et al., 1998). The HSI were significantly decreased in all p, $\mathrm{p}^{\prime}$-DDE treatments in this study (Table 2). Both field and laboratory studies on fish have reported decreases in HSI upon exposure to organic contaminants (Van der Oost et al., 2003). These results suggested that dysfunctions in the liver of rare minnow occurred following exposure to atrazine and p,p'-DDE.

Hypertrophy of hepatocytes indicated by increased cell size was observed at the highest concentration of atrazine (333 $\mu \mathrm{g} / \mathrm{l}$; Fig. 1B and E). According to Zaroogian et al. (2001) and Purdom et al. (1994) the increase of liver cell size was suggested to be an indicator of accelerated hepatic protein synthesis. There have been evidences showing that VTG was the main circulating protein that increased with exogenous estrogen treatment (Schultz et al., 2001; Zha et al., 2007; Zhong et al., 2004). So it was likely that exposure to atrazine induced the synthesis of VTG in the liver of rare minnow, thus resulted in hypertrophy of hepatocytes (presented as increased size), and finally increase of the HSI. Besides atrophy of hepatocytes in all p, $\mathrm{p}^{\prime}$-DDE treatments (Fig. 1D), vacuolization was also observed in the liver of rare minnow treated by p,p'-DDE (Fig. 1F). According to Hinton and Laurén (1990), these lesions were probably due to the loss of lipids or nuclear and cytoplasmic inclusions caused by oxidative stress. Dowling et al. (2006) and Hoarau et al. (2004) have proved that $\mathrm{p}, \mathrm{p}^{\prime}$-DDE generated reactive oxygen species (i.e. indicated by glutathione S-transferase activity) which 
could result in oxidative stress in clam (Ruditapes decussates). It was possible that in this study the histopathological lesions and decreased HSI were caused by oxidative stress in the liver of rare minnow generated by $\mathrm{p}, \mathrm{p}^{\prime}$-DDE. All in all, these results suggested that atrazine and $\mathrm{p}, \mathrm{p}^{\prime}$-DDE could cause adverse effects on the liver of rare minnow.

Real-time PCR assays were established to evaluate the relative expression of liver $h s p 70, h s p 90$, ar, er and gr when adult fish were exposed to environmentally relevant concentrations of atrazine and p, $\mathrm{p}^{\prime}$-DDE. With the advances in molecular approaches, the application of toxicogenomics could be a powerful tool for evaluating the effects and discovering molecular mechanisms underlying toxic response (Nie et al., 2006). Both atrazine and p,p'-DDE have been proved to interfere with the steroid signaling pathways in aquatic organisms (Hayes et al., 2002; Kelce et al., 1995), however their effects on the HSPs have been rarely reported.

According to Crain et al. (1997) atrazine promoted the conversion from androgen to estrogen by inducing the activity of aromatase. The increased HSI and histopathological observations in this study also indicated estrogenic effects on the liver of rare minnow. Real-time PCR results in this study showed dose-dependent increases in liver ar and er mRNA (Fig. 2), indicating that both estrogen and androgen pathways were promoted at the gene level. Moreover, both changes in the HSI and the expression of ar indicated that female rare minnow was more sensitive in response to atrazine exposure. Greater responses to external stimulation in matured females than males have been reported in chinook salmon and rainbow trout (McQuillan et al., 2003). No effect on liver $g r$ mRNA was observed in rare minnow treated by atrazine. However, disruptions in synthetic pathway of glucocorticoid have been reported in adrenocortical steroidogenic cells of rainbow trout (Bisson and Hontela, 2002). These results suggested that the interference of atrazine with the adrenal system were tissue specific. Real-time PCR results also indicated increases in the expression of liver hsp70 mRNA (all treatments except for $333 \mu \mathrm{g} / \mathrm{l}$ in females) and $h s p 90$ mRNA ( 3 and $333 \mu \mathrm{g} / \mathrm{l}$ in both males and females) in rare minnow treated by atrazine (Fig. 3 ). Increased HSPs have been reported in liver, ovary and gill in tilapia (Oreochromis niloticus) and rainbow trout (Vijayan et al., 2000). It was supposed that the upregulation of HSPs might be a mechanism for increasing the stress threshold and enhancing self-protection (Vijayan et al., 2003). According to Welshons et al. (2003), different mechanisms may be in charge of the response to stress by varying doses of environmental contaminants. We suppose that enhanced self-protection was mainly achieved by increasing the expression of $h s p 70$ which could facilitate the folding of hormone-binding domain and activation of the steroid receptors (Pratt, 1993) at the medium concentrations $(10,33,100 \mu \mathrm{g} / \mathrm{l})$ of atrazine, while promotions of $h s p 90$ which could increase the stability of the heterocomplex by preventing proteasomal degradation of the steroid receptors (Segnitz and Gehring, 1997) were also required at the lower $(3 \mu \mathrm{g} / \mathrm{l})$ and higher $(333 \mu \mathrm{g} / \mathrm{l})$ concentrations. The expression of liver $h s p 70$ and hsp90 was altered under the same conditions as changes in ar and er expression. This suggests either direct or indirect endocrine modulating effects of atrazine and is also consistent with a possible chaperone role of HSPs for estrogen and androgen receptors in the rare minnow.

The metabolite p,p'-DDE has been proven to be a potent androgen antagonist (Kelce et al., 1995). However, Li et al. (2008) found in their studies using a battery of recombinant yeast assay that many pollutants could interfere with more than one receptor. In this study, the expression of ar, er and gr showed dose-dependent decreases in $\mathrm{p}, \mathrm{p}^{\prime}$-DDE treatments. Consistent with our results, Larkin et al. (2002) using gene array technology reported that p,p'DDE could decrease the expression of ar, er and $g r$ in the liver of female largemouth bass (Micropterus salmoides). Park et al. (2007) reported similar results in their study of wild tilapia, and also found the suppressing effects were tissue specific. As a protective effect of glucocorticoids has been proved against oxidative stress induced by extrinsic contaminant in rats (Rattus norvegicus) (Montilla et al., 2004), the decreased HSI and histopathological lesions due to depletion of lipids or nuclear and cytoplasmic inclusions, as previously described, were more likely to be related to the disruption of gr signaling pathway in the liver of rare minnow by p, $\mathrm{p}^{\prime}$-DDE. Meantime, $h s p 70$ and $h s p 90$ mRNA were both significantly suppressed in the liver of rare minnow exposed to $\mathrm{p}, \mathrm{p}^{\prime}$-DDE, indicating that the protecting mechanism of HSPs had been blocked. Overall, simultaneous down-regulated expression of liver $a r, e r, g r$ as well as $h s p 70$ and $h s p 90$ suggested that the action on steroid receptors were probably accompanied by p,p'-DDE action on HSPs in the liver of the rare minnow. As in the case of atrazine effects, these results are consistent with direct effects of p,p'-DDE on steroid receptors and possible indirect effects involving the chaperone role of HSPs.

\section{Conclusions}

The alterations in expression of steroid receptors ( $a r, e r$ and $g r$ ) caused by atrazine and p, $\mathrm{p}^{\prime}$-DDE exposure were accompanied by changes of $h s p 70$ and $h s p 90$ expression in rare minnow. Therefore, the heat shock proteins (HSPs) were likely to play chaperon roles for the steroid receptors in vivo, consistent with previous in vitro results.

\section{Acknowledgements}

This work was supported by Chinese Academy of Sciences (KZCX2-YW-Q02-05), National Basic Research Program of China (2009CB421605), and the National Natural Science Foundation of China (20737003). We would like to thank Professor Spear Philip from Centre de recherche TOXEN and Département des Sciences Biologiques, Université du Québec à Montréal for revising this manuscript.

\section{References}

Bisson, M., Hontela, A., 2002. Cytotoxic and endocrine-disrupting potential of atrazine, diazinon, endosulfan, and mancozeb in adrenocortical steroidogenic cells of rainbow trout exposed in vitro. Toxicol. Appl. Pharm. 180, 110-117.

Christiansen, L.B., Pedersen, K.L., Korsgaard, B., Bjerregaard, P., 1998. Estrogenicity of xenobiotics in rainbow trout (Oncorhynchus mykiss) using in vivo synthesis of vitellogenin as a biomarker. Mar. Environ. Res. 46, 137-140.

Crain, D.A., Guillette Jr., L.J., Rooney, A.A., Pickford, D.B., 1997. Alterations in steroidogenesis in alligators (alligator mississippiensis) exposed naturally and experimentally to environmental contaminants. Environ. Health Perspect. 105, 528-533.

Dong, L., Chen, L., Li, Z., Gao, H., Li, J., 2006. Quality assurance/quality control for monitoring and analysis of trace triazines in water. J. Safe Environ. 6, 35-38.

Dowling, V., Hoarau, P.C., Romeo, M., O’Halloran, J., van Pelt, F., O’Brien, N., Sheehan, D., 2006. Protein carbonylation and heat shock response in Ruditapes decussatus following, p,p'-dichlorodiphenyldichloroethylene (DDE) exposure: a proteomic approach reveals that DDE causes oxidative stress. Aquat. Toxicol. 77, 11-18.

Harshbarger, J.C., Coffey, M.J., Young, M.Y., 2000. Intersexes in Mississippi River shovelnose sturgeon sampled below Saint Louis, Missouri, USA. Mar. Environ. Res. $50,247-250$.

Hayes, T.B., Collins, A., Lee, M., Mendoza, M., Noriega, N., Stuart, A.A., Vonk, A., 2002 Hermaphroditic, demasculinized frogs after exposure to the herbicide atrazine at low ecologically relevant doses. Proc. Natl. Acad. Sci. 99, 5476-5480.

Hinton, D.E., Laurén, D.L., 1990. Liver structural alterations accompanying chronic toxicity in fishes: potential biomarkers of exposure. In: McCarthy, J., Shugart, L.R. (Eds.), Biological Markers of Environmental Contamination. Lewis Publishing Inc., Chelsea, Michigan, pp. 17-57.

Hoarau, P., Garello, G., Gnassia-Barelli, M., Romeo, M., Girard, J.P., 2004. Effect of three xenobiotic compounds on glutathione S-transferase in the clam (Ruditapes decussates). Aquat. Toxicol. 68, 87-94.

Kelce, W.R., Stone, C.R., Laws, S.C., Earl Gray, L., Kemppainen, J.A., Wilson, E.M., 1995 Persistent DDT metabolite p, $\mathrm{p}^{\prime}$-DDE is a potent androgen receptor antagonist. Nature 375, 581-1581.

Kokolakis, G., Panagis, L., Stathopoulos, E., Giannikaki, E., Tosca, A., KrügerKrasagakis, S., 2008. From the protein to the graph: how to quantify 
immunohistochemistry staining of the skin using digital imaging. J. Immunol. Methods 331, 140-146.

Korsgaard, B., Emmersen, J., Petersen, I.M., 1983. Estradiolinduced hepatic protein synthesis and transaminase activity in the male flounder (Paralichthys flesus). Gen. Comp. Endocrinol. 50, 11-17.

Larkin, P., Sabo-Attwood, T., Kelso, J., Denslowa, N.D., 2002. Gene expression analysis of largemouth bass exposed to estradiol, nonylphenol, and p,p'-DDE. Comp. Biochem. Physiol. B 133, 543-557.

Li, J., Li, N., Ma, M., Giesy, J.P., Wang, Z., 2008. In vitro profiling of the endocrine disrupting potency of organochlorine pesticides. Toxicol. Lett. 183, 65-71.

Li, W., Zha, J., Li, Z., Yang, L., Wang, Z., 2009. Changes of thyroid hormone levels and related gene expression in Chinese rare minnow (Gobiocypris rarus) during 3-amino-1,2,4-triazole exposure and recovery. Aquat. Toxicol. 92, 50-57.

McLachlan, J.A., 1993. Functional toxicology: a new approach to detect biologically active xenobiotics. Environ. Health Perspect. 101, 386-387.

McQuillan, H., Lokman, P., Young, G., 2003. Effects of sex steroids, sex, and sexual maturity on cortisol production: an in vitro comparison of chinook salmon and rainbow trout interrenals. Gen. Comp. Endocrinol. 133, 154-163.

Montilla, P., Tuǐnez, I., Muñ̃oz, M.C., Salcedo, M., Feijoǐo, M., Muñoz-Castañeda, J.R., Bujalance, I., 2004. Effect of glucocorticoids on 3-nitropropionic acid-induced oxidative stress in synaptosomes. Eur. J. Pharm. 488, 19-25.

Nie, A.Y., McMillian, M., Parker, J.B., Leone, A., Bryant, S., Yieh, L., Bittner, A., Nelson, J., Carmen, A., Wan, J., Lord, P.G., 2006. Predictive toxicogenomics approaches reveal underlying molecular mechanisms of nongenotoxic carcinogenicity. Mol. Carcinog. 45, 914-933.

Ojima, N., Yamashita, M., Watabe, S., 2005. Quantitative mRNA expression profiling of heat-shock protein families in rainbow trout cells. Biochem. Biophys. Res. Commun. 329, 51-57.

Park, C., Takemura, A., Aluru, N., Park, Y., Kim, B., Lee, C., Lee, Y., Moon, T.W., Vijayan, M.M., 2007. Tissue-specific suppression of estrogen, androgen and glucocorticoid receptor gene expression in feral vitellogenic male Mozambique tilapia. Chemosphere 69, 32-40.

Peris, E., Requena, S., de la Guardia, M., Pastor, A., Carrasco, J.M., 2005. Organochlorinated pesticides in sediments from the Lake Albufera of Valencia (Spain). Chemosphere 60, 1542-1549.

Pratt, W.B., 1993. The role of heat shock proteins in regulating the function, folding, and trafficking of the glucocorticoid receptor. J. Biol. Chem. 268, 21455-21458.

Purdom, C.E., Hardiman, P.A., Bye, V.J., Eno, N.C., Tyler, C.R., Sumpter, J.P., 1994. Estrogenic effects of effluents from sewage treatment works. Chem. Ecol. 8, 275-285.

Reik, A., Sch"utz, G., Stewart, A.F., 1991. Glucocorticoids are required for establishment and maintenance of an alteration in chromatin structure: induction leads to a reversible disruption of nucleosomes over an enhancer. EMBO J. 10, 2569-2576.

Ren, J., Jiang, K., Zhou, H., 2002. The concentration and source of Atrazine residue in water of guanting reservoir. Environ. Sci. 23, 126-128.

Scherrer, L.C., Dalman, F.C., Massa, E., Meshinchi, S., Pratt, W.B., 1990. Structural and functional reconstitution of the glucocorticoid receptor-hsp90 complex. J. Biol. Chem. 265, 21397-21400.
Schultz, I.R., Orner, G., Merdink, J.L., Skillman, A., 2001. Dose-response relationships and pharmacokinetics of vitellogenin in rainbow trout after intravascular administration of 17 alpha-ethynylestradiol. Aquat. Toxicol. 51, 305-318.

Segnitz, B., Gehring, U., 1997. The function of steroid hormone receptors is inhibited by the hsp90-specific compound geldanamycin. J. Biol. Chem. 272, 18694-18701.

U.S. EPA, 2002. Reregistration Eligibility Science Chapter for Atrazine Environmental Fate and Effects Chapter. U.S. EPA, Washington, DC, USA.

Van der Oost, R., Beyer, J., Vermeulen, N.P.E., 2003. Fish bioaccumulation and biomarkers in environmental risk assessment: a review. Environ. Toxicol. Pharmacol. 13, 57-149.

Vijayan, M.M., Campbell, T., Strutt, E., Sathiyaa, R., 2000. Cortisol modulates heat shock protein expression in primary cultures of rainbow trout hepatocytes. In: Proceedings of the 4th International Symposium on Fish Endocrinology, Seattle, WA.

Vijayan, M.M., Raptis, S., Sathiyaa, R., 2003. Cortisol treatment affects glucocorticoid receptor and glucocorticoid-responsive genes in the liver of rainbow trout. Gen. Comp. Endocrinol. 132, 256-263.

Wang, J.W., 1992. Reproductive biology of Gobiocypris rarus. Acta Hydrobiol. 16, $165-174$.

Welshons, W.V., Thayer, K.A., Judy, B.M., Taylor, J.A., 2003. Large effects from small exposures. Mechanisms for endorcrine-disrupting chemicals with estrogenic activity. Environ. Health Perspect. 111, 944-1006.

Whitesell, L., Cook, P., 1996. Stable and specific binding of heat shock protein 90 by geldanamycin disrupts glucocorticoid receptor function in intact cells. Mol. Endocrinol. 10, 705-712.

Wolf, J.C., Dietrich, D.R., Friederich, U., Caunter, J., Brown, A.R., 2004. Qualitative and quantitative histomorphologic assessment of fathead minnow (Pimephales promelas) gonads as an endpoint for evaluating endocrine-active compounds: a pilot methodology study. Toxicol. Pathol. 32, 600-612.

Xue, N., Zhang, D., Xu, X., 2006. Organochlorinated pesticide multiresidues in surface sediments from Beijing Guanting reservoir. Water Res. 40, 183-194.

Zaroogian, G., Gardner, G., Horowitz, B.D., Gutjahr-Gobell, R., Haebler, R., Mills, L., 2001. Effect of 17b-estradiol, o,p'-DDT, octylphenol and p,p'-DDE on gonadal development and liver and kidney pathology in juvenile male summer flounder (Paralochthys dentatus). Aquat. Toxicol. 54, 101-112.

Zha, J., Sun, L., Zhou, Y., Spear, P., Ma, M., Wang, Z., 2007. Assessment of $17 \alpha$-ethinylestradiol effects and underlying mechanisms in a continuous, multigeneration exposure of the Chinese rare minnow (Gobiocypris rarus). Toxicol. Appl. Pharm. 226, 298-308.

Zhang, X., Zha, J., Li, W., Yang, L., Wang, Z., 2008. Effects of 2,4-dichlorophenol on the expression of vitellogenin and estrogen receptor genes and physiology impairments in Chinese rare minnow (Gobiocypris rarus). Environ. Toxicol. 23, 694-701.

Zhong, X., Xu, Y., Liang, Y., Liao, T., Wang, J., 2004. Vitellogenin in rare minnow (Gobiocypris rarus): identification and induction by waterborne diethylstilbestrol. Comp. Biochem. Physiol. C 137, 291-298. 